\title{
Integrated Modeling of Groundwater and Surface Water Interactions in a Manmade Wetland
}

\author{
Guobiao Huang ${ }^{1, *}$ and Gour-Tsyh Yeh ${ }^{2}$ \\ ${ }^{1}$ California Department of Water Resources, Sacramento, California, USA \\ ${ }^{2}$ Graduate Institute of Applied Geology, National Central University, Jhongli, Taiwan
}

Received 30 September 2011, accepted 17 April 2012

\begin{abstract}
A manmade pilot wetland in south Florida, the Everglades Nutrient Removal (ENR) project, was modeled with a physicsbased integrated approach using WASH123D (Yeh et al. 2006). Storm water is routed into the treatment wetland for phosphorus removal by plant and sediment uptake. It overlies a highly permeable surficial groundwater aquifer. Strong surface water and groundwater interactions are a key component of the hydrologic processes. The site has extensive field measurement and monitoring tools that provide point scale and distributed data on surface water levels, groundwater levels, and the physical range of hydraulic parameters and hydrologic fluxes. Previous hydrologic and hydrodynamic modeling studies have treated seepage losses empirically by some simple regression equations and, only surface water flows are modeled in detail. Several years of operational data are available and were used in model historical matching and validation. The validity of a diffusion wave approximation for two-dimensional overland flow (in the region with very flat topography) was also tested. The uniqueness of this modeling study is notable for (1) the point scale and distributed comparison of model results with observed data; (2) model parameters based on available field test data; and (3) water flows in the study area include two-dimensional overland flow, hydraulic structures/levees, three-dimensional subsurface flow and one-dimensional canal flow and their interactions. This study demonstrates the need and the utility of a physics-based modeling approach for strong surface water and groundwater interactions.
\end{abstract}

Key words: Integrated model, Manmade wetland, Surface and groundwater interaction, WASH123D

Citation: Huang, G. and G. T. Yeh, 2012: Integrated modeling of groundwater and surface water interactions in a manmade wetland. Terr. Atmos. Ocean. Sci., 23, 501-511, doi: 10.3319/TAO.2012.04.17.02(WMH)

\section{INTRODUCTION}

Manmade treatment wetlands have been extensively used for wastewater treatment or stormwater nutrient removal in the USA. Typically, these surface water impoundments are built for flow-through treatment of storm water by plant and sediment uptakes of both nutrients and pollutants. In south Florida, the Everglades restoration effort has led to the design and construction of a series of constructed wetlands, called Storm water Treatment Areas (STAs), to reduce phosphorus levels in storm water runoff before they can enter protected areas of the Everglades. These constructed wetlands were located on former natural wetlands or farmland. The Everglades Nutrient Removal (ENR) project is a pilot constructed wetland for STAs (SFWMD 2000).

\footnotetext{
* Corresponding author

E-mail: ghuang@water.ca.gov
}

In south Florida, the regional hydrogeology has been characterized as a surficial aquifer (Fish 1988). Wetlands in the region have strong hydraulic connections with the underlying, highly conductive surficial aquifer. Harvey et al. (2002) studied the surface and groundwater interactions in the ENR and surrounding wetlands with field investigations.

Guardo studied water budgeting in the ENR with a simple water mass balance approach (Guardo 1999). Regression models were used to estimate groundwater seepages in ENR and the whole ENR was treated as a single unit for water budget. Guardo and Tomasello (1995) simulated overland flow in ENR using a steady hydrodynamic model. Until recently, the hydraulic models applied to the design and management of constructed wetlands are quite limited in scope and detail. Most models are two-dimensional, for 
steady-state flow. They are good for both design purposes or as a screening tool, but lack important details incorporating hydraulic structures, calibrated model parameters and surface/groundwater interaction. More detailed two-dimensional hydraulic models, used in the existing treatment of wetlands, are being built for management and operation needs. They are calibrated and validated with historic time series data, considering only the two-dimensional surface flow.

Some popular hydrodynamic computer codes currently used for modeling wetland hydraulics were originally developed for coastal hydrodynamic modeling. Some limitations need to be addressed before they can be applied for wetland simulation with regard to the incorporation of hydraulic structures, explicit representation of rainfall, and evaporation and treatment of wetting and drying are very important in a wetland hydrologic model.

Swain et al. (2004) have described their experience in adapting and modifying the USGS SWIFT2D, originally developed for coastal tidal flow, to simulate the southern Everglades wetland hydrology. A watershed model code, such as WASH123D (Yeh et al. 2006) does not have these limitations. This WASH123D application is an example of coupled surface/subsurface water flows in a constructed wetland for storm water treatment in south Florida. Current two-dimensional hydraulic models cannot handle seepage loss properly; therefore, an integrated surface/groundwater model is needed to study the dynamic interaction of surface flow within the treatment area and seepage loss through bottom and perimeter levees. A one-dimensional canal flow is also needed to simulate inflow/outflow and seepage collection. The impact of neglecting seepage loss is a likely distorted hydraulic model.

Wetland hydrological modeling studies have been increasingly reported in the hydrology literature. Feng and Molz (1997) developed a surface water flow model for wetlands incorporating a diffusion wave approximation of twodimensional shallow water equations. The model was tested with a field application. However, a model history matching was not reported. Few integrated wetland hydrologic modeling studies have been reported. MIKE SHE was applied to a natural wetland in England (Thompson et al. 2004), while Langevin et al. (2005) used an integrated model in a coastal natural wetland by coupling SWIFT2D and MODFLOW.

The purpose of a hydraulic model for a constructed wetland is to evaluate the hydraulic performance under different flow conditions. If the transport and fate of phosphorus can be described as biogeochemical reactive transport equations, then the hydrodynamic component is also the base of the reactive transport computation. All these modeling objectives are likely to be more effectively modeled in an integrated model code such as WASH123D.

The objective of this paper is to present a field study that demonstrates and validates the applicability of a phys- ics-based, integrated modeling approach for surface water and groundwater interactions in wetlands; in addition, it seeks to show how field data from previous field studies can be used in building the integrated model with minimum model historical matching. Historical time series data and field test results were applied in evaluating the model performance.

\section{SITE DESCRIPTION}

The ENR project (Figs. 1 and 2) was built as a prototype treatment wetland in south Florida, USA, for the Everglades restoration (SFWMD 2000). It was operated for five years (1994 to 1999) and is now incorporated into the Stormwater Treatment Area 1 west (STA-1W).

The total surface area of the ENR is about 16 square kilometers. The land surface elevations were based on previous field survey data. Marsh area elevations range from $2.0 \mathrm{~m}$ NGVD29 (National Geodetic Vertical Datum of $1929)$ to $4.0 \mathrm{~m}$ NGVD29. The average land surface gradient is 0.001 . The ENR basin topography is very flat that is typical in south Florida.

The vegetation in the ENR was spatially varied and changed over time. The main treatment plants were emergent cattail and submerged aquatic vegetation (SAV). There were also some local distribution canals and remnant farm ditches in the marsh areas.

The ENR basin has been extensively monitored and studied by the South Florida Water Management District (SFWMD) and USGS (SFWMD 2000; Harvey et al. 2002). The measured time series data were recorded in the SFWMD corporate database DBHYDRO (SFWMD 2005).

\section{WATER FLOW}

As can be seen in Fig. 2, the ENR basin is separated from the surrounding areas by a perimeter levee. The eastern boundary of subsurface flow is controlled by water levels in the Water Conservation Area 1 (WCA-1). The seepage canal, running along the western and northern boundary, controls the remaining boundaries. The bottom boundary can be considered impermeable, since field studies have found that groundwater flow in the surficial aquifer to be predominantly horizontal. Generally, groundwater received a recharge from the WCA-1, where the water levels were normally regulated between $4.88 \mathrm{~m} \mathrm{NGVD}$ to $5.18 \mathrm{~m} \mathrm{NGVD} \mathrm{(16-}$ $17 \mathrm{ft}$ NGVD), while discharge was mainly through the seepage canal. Subsurface flow also received a recharge through overland flow infiltration.

Surface water flow in the ENR basin is controlled by a series of pump stations and gated culverts. The ENR consists of a buffer cell and four treatment cells 1 - 4 (Fig. 2). Storm water runoff was pumped into the buffer cell and distributed to the eastern flow way (Cell 1 and Cell 3) and the 
western flow way (Cell 2 and Cell 4). Interior levees separated each treatment cell from one another and a series of culverts with risers were built in the interior levees to control flows among cells. Treated water from the western flow way was directed to Cell 3 by the gated culverts G-256 and eventually, was discharged from ENR into WCA-1 through the outflow pump station G-251.

The major surface water inflow and outflow are through pumping stations G-250 and G-251. Structure inflows consisted of the inflow pump station G-250 and seepage return pump G-250S. Structure outflow was through outflow pump station G-251. Discharge into the seepage canal could be made through gated structures G-258 and G-259. The current modeling study simulated the whole calendar year of 1998. During this time period, outflow from G-258 and G-259 was zero.

\section{MODEL TOOL: WASH123D}

This is a generic, integrated surface water/groundwater interaction model code (Yeh et al. 2006). It can simulate a one-dimensional channel network, two-dimensional

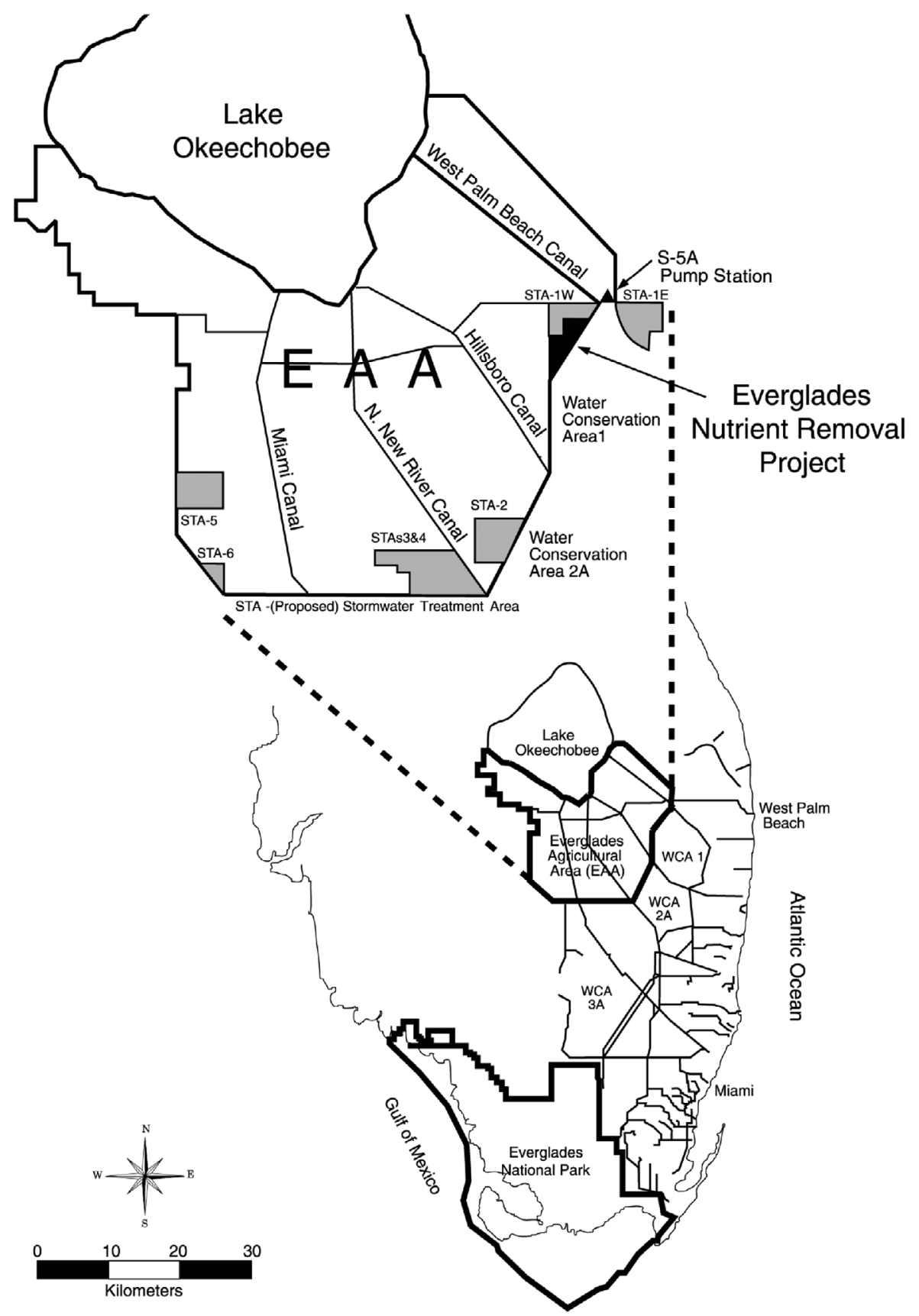

Fig. 1. Location map of ENR (SFWMD 2000). 


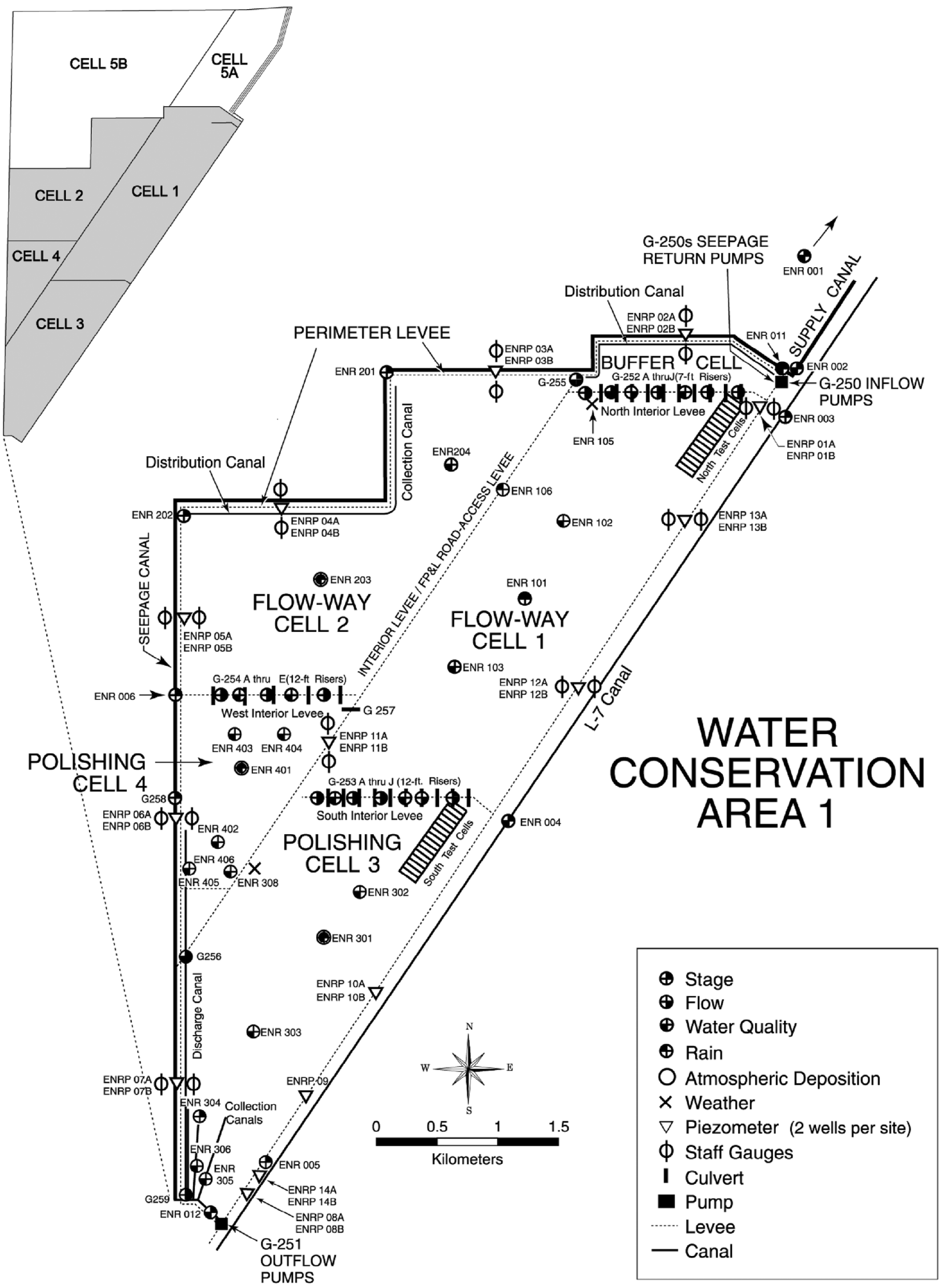

Fig. 2. Schematic map of ENR and location of observations (modified after SFWMD 2000). 
overland flows, and three-dimensional variably saturated subsurface flow, separately. When needed, it can also simulate different combinations of coupled surface water and subsurface water flows.

Some adaptations and modifications were easily implemented into the source code for this modeling effort. The original WASH123D code applies constant friction coefficient (Manning's $n$ value) for bottom shear stresses. But the dense vegetation in the marsh area requires a water depth dependent Manning's n relationship. Different depth dependent relationships can be easily applied by a tabular (depthn) profile input in WASH123D. The calibrated flow rating equations for various hydraulic structures can also be coded in WASH123D that control the water transfer between different canal locations or from/to canal to overland (marsh area).

\section{INPUT DATA}

Time series data of rainfall, evapotranspiration, structure flow, and surface and ground water levels were retrieved from the public accessible DBHYDRO database (SFWMD 2005).

Daily rainfall was measured via a network of rain gauges throughout the ENR area and a spatially averaged daily rainfall time series was directly obtained from DBHYDRO. Daily potential evapotranspiration data was based on a regression equation derived from three lysimeter measurements (Abtew and Obeysekera 1995; Abtew 1996) and was also available in the database.

Structure flow data was computed by SFWMD using calibrated flow rating equations. Normally, these flow data were not as accurate as data from measured water levels.

\section{MODEL SETUP}

The conceptualization of the study area leads to conclusion ending in a relatively closed flow system. In reality, storm water runoff was pumped into the buffer cell and flow into the treatment cells through control structures. The treated water is discharged at the downstream by the outflow pump station G251 and eventually entered the WCA-1.

The surface water flows were simulated as two-dimensional overland flow. Current model simulations applied the diffusion wave approximation of the full shallow water equations for overland flow. The entire overland flow domain was discretized into 1345 linear triangular elements and 746 nodes. The average length of a triangular side was about $160 \mathrm{~m}$. The interior levee was represented by inactive elements and water could go only through it by structure flows. The known inflow pumping rate was applied by a water source term in the overland domain. A specified stage boundary condition was applied at the downstream outflow location (G-251 headwater).
Vegetation was planted in the treatment cells (Fig. 3). They are categorized as emergent cattails and SAV. Previous studies have demonstrated that a water depth dependent friction coefficient is appropriate for vegetation (Yen 1992; Wu et al. 1999). Field study at ENR showed that the Manning's $\mathrm{n}$ values range from 0.1 to 1.5 depending on water depth and submergence level of the plants.

For subsurface flow, the surficial aquifer system was simulated with the three-dimensional Richards equation governing the variably saturated subsurface flow. The underlying surficial aquifer was vertically divided into several layers, the top layers, extending from land surface to a few feet in thickness, is the less permeable peat soil; the next lower layers are composed of sand or sandy lime rock. Figure 4 shows the three-dimensional finite element mesh for subsurface flow. For this preliminary simulation, the model domain was selected up to the location of the seepage canal to the west, and the L-7 canal to the east. These canals are hydraulic divides for subsurface flow.

The hydrogeology was obtained from some relevant reference sources (Fish 1988; Harvey et al. 2002). Harvey et al. (2002) described detailed local hydro-geological data for the ENR area. The value of saturated hydraulic conductivity and effective porosity used in the final model runs are listed in Table 1. The Van Genucheten equations were used to derive the nonlinear relationships for soil hydraulic property.

The subsurface flow domain consisted of 9415 elements and 5968 nodes. The peat soil made up the top three layers; the next two layers were for sandy limestone and the bottom two coarser layers with the maximum depth of $36.5 \mathrm{~m}$ (120 ft.) from the surface. This subsurface element resolution was designed to maintain a balance between run time requirements for long-term model runs and model accuracy.

Specified head boundary conditions were applied for the WCA- 1 and the seepage canal for current model simulations. The seepage canal could be simulated by the one-dimensional channel flow and coupled with subsurface flow. However, the water levels in the canal were kept below $2.4 \mathrm{~m} \mathrm{NGVD} \mathrm{(} 8 \mathrm{ft} \mathrm{NGVD)}$ to protect farmlands adjacent to the ENR; canal flow was quite static. Therefore it was considered as a specified head boundary for subsurface flow and it had no hydraulic connection with the overland flow during model simulations. No interface sediment layers were assumed to exist between subsurface and overland or canal. So both continuity of pressure head and exchange flux were imposed for surface water and groundwater interactions.

\section{MODEL HISTORICAL MATCHING AND VALI- DATION}

The integrated model was calibrated and validated with both historical stage and ground water level data. Theoretically, most model parameters in a physics-based model 


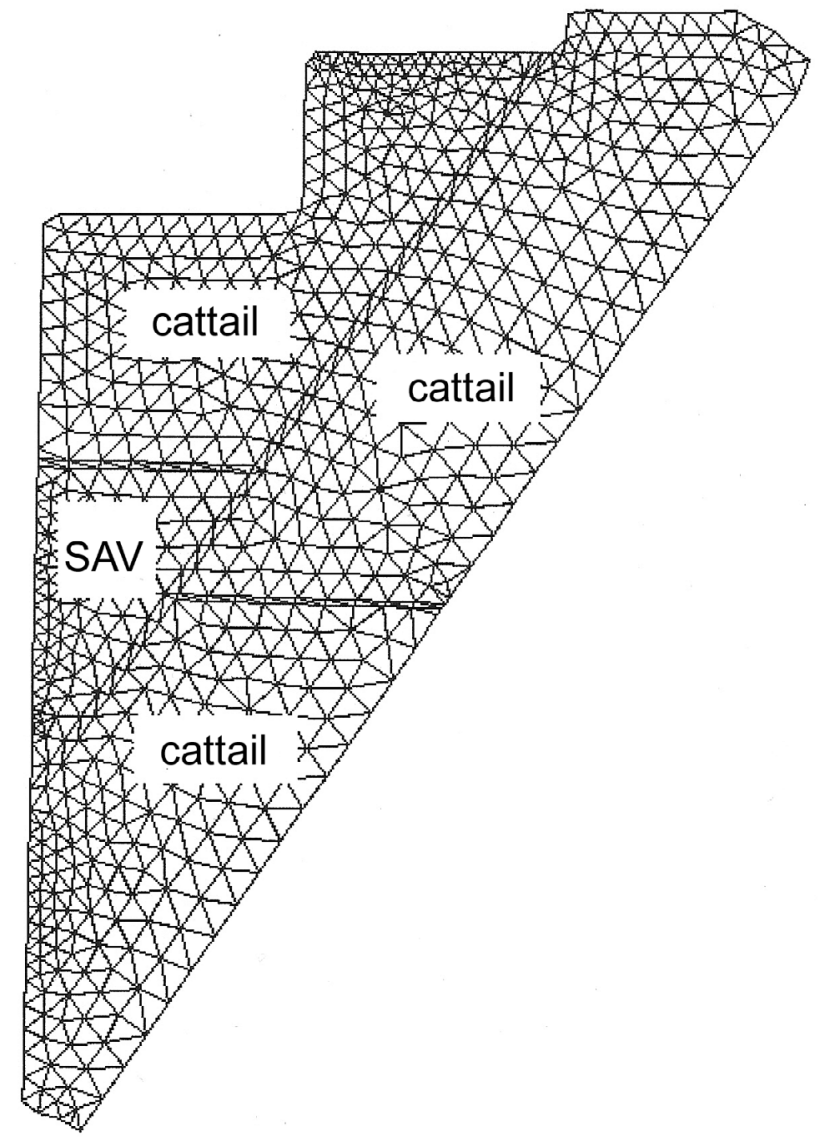

Fig. 3. Vegetation types as simulated in the model.

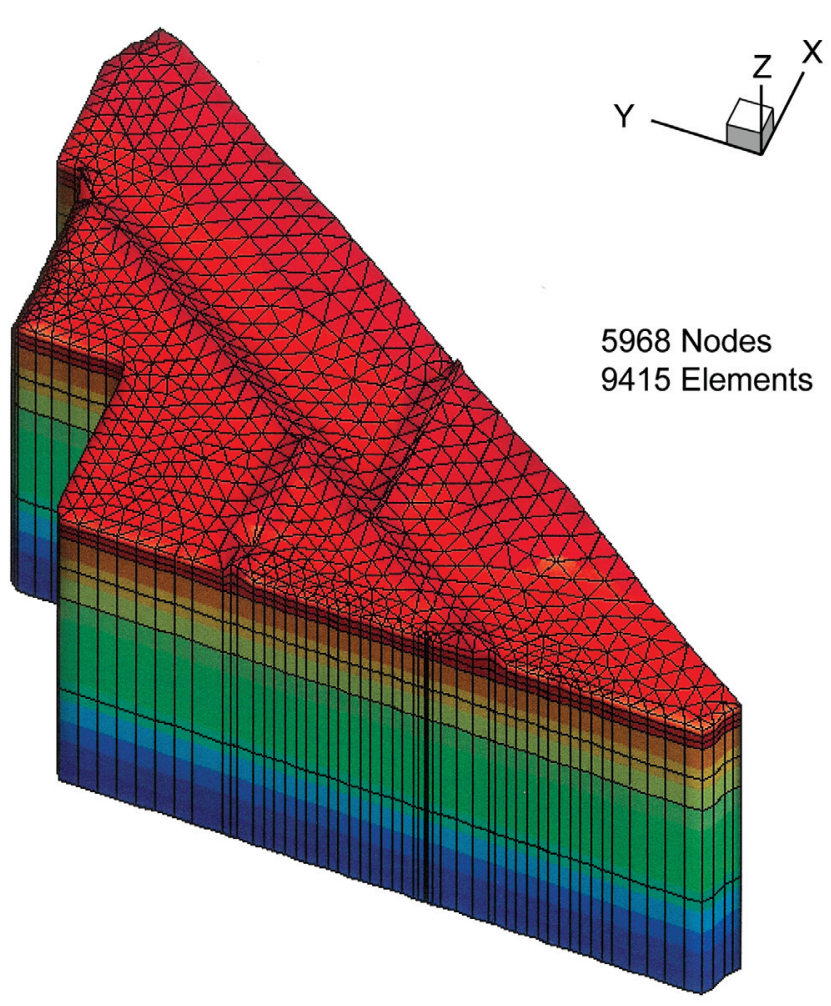

Fig. 4. Finite element meshes for ENR basin.
Table 1. Hydraulic properties for subsurface flow.

\begin{tabular}{lccc}
\hline \multirow{2}{*}{ Soil type } & Porosity & \multicolumn{2}{c}{ Hydraulic Conductivity } \\
\cline { 3 - 4 } & & $\begin{array}{c}\text { Horizontal } \\
\left(\mathbf{c m ~ d a y}^{-1}\right)\end{array}$ & $\begin{array}{c}\text { Vertical } \\
\left(\mathbf{c m}^{-1} \text { day }^{-1}\right)\end{array}$ \\
\hline Peat & 0.21 & 9.14 & 1.46 \\
Sandy limestone & 0.31 & 277.98 & 28.97 \\
Sand & 0.41 & 2070.20 & 209.93 \\
\hline
\end{tabular}

are measurable physical properties and can be estimated through field studies. The ENR field studies (e.g., SFWMD 2000 and Harvey et al. 2002) provided the physical range for saturated hydraulic conductivity and the Manning's n. However, due to spatial heterogeneity and limited sampling sites, minimum model historical matching is still needed to better capture historic trends and this represents the averaging and upscale uncertainty from point sampling to element level.

The split sample approach was used to calibrate and validate the ENR model. The time period from 7/1/1998 to $12 / 31 / 1998$ was used for model historical matching and the period from $1 / 1 / 1998$ to $6 / 30 / 1998$ was used in model validation. The model parameters used in model historical matching were the Manning's $\mathrm{n}$ for overland flow and the hydraulic conductivity for subsurface flow. The initial conditions for model history matching and validation were estimated from observed surface water levels, flow rate and groundwater levels.

The model performance was judged by mean error, absolute mean error, and root mean square error, and $\mathrm{R}^{2}$ between observed and computed time-series stages and groundwater levels.

\section{MODEL SIMULATION RESULTS}

The preliminary model simulation results (from 1/1/ 1998 to 12/31/1998) are presented and discussed as follows. The average hydraulic conductivity values from model calibration (Table 1) were used for subsurface flow. The adjusted Manning's n range from 0.025 to 0.5 , varied with different vegetation or open water.

\subsection{Surface Water Flow}

G250 inflow pumping mainly controlled two-dimensional overland flow conditions. Rainfall and evapotranspiration were a small part of the water budget. The spatial distribution of vegetation and the flow distribution among treatment cells are important factors.

The comparison of computed and observed surface water levels at the center of each treatment cell is shown in Figs. 5 to 8. The variation in water levels in both flow ways was captured quite well for Cell 1 (ENR101), Cell 2 


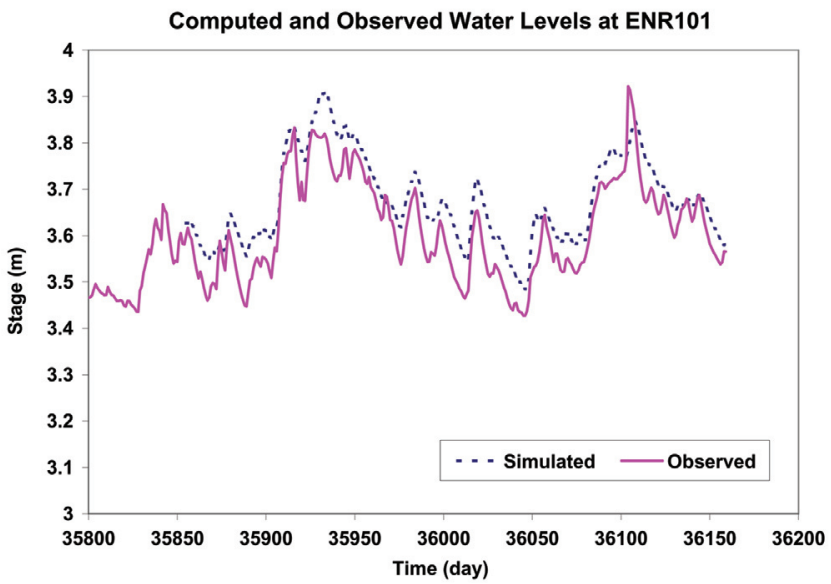

Fig. 5. Simulated and observed surface water levels at ENR101.

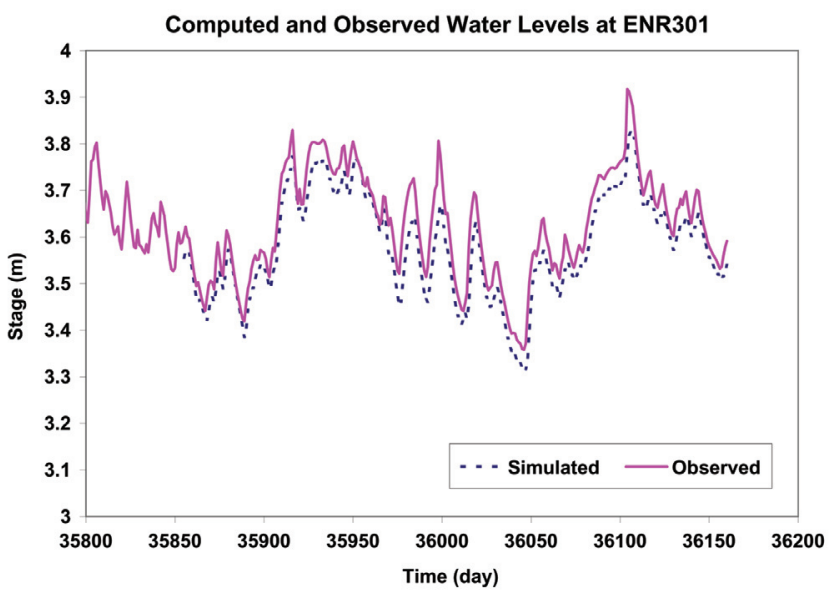

Fig. 7. Simulated and observed surface water levels at ENR203.

(ENR203), Cell 3 (ENR301) and Cell 4 (ENR401). The R ${ }^{2}$ values for these four locations were between 0.85 and 0.95 . The mean absolute error and mean error values were relatively small for the simulation period (Table 2).

\subsection{Subsurface Flow}

The observed and computed groundwater levels at ENR102GW, ENR204GW, ENR401GW and ENR303GW are compared in Figs. 9 through 12. The simulation results are similar to those of surface water levels. The largest average absolute error was $19 \mathrm{~cm}$ for ENR401GW in Cell 4. The relatively large bias at this location may be reduced by further model calibration runs. The simulation errors are summarized in Table 3.

The unsaturated zone was thin and localized during the simulation period. During the dry season, a large portion of the surface area could dry up and soil moisture could be less than saturated; under this flow condition, use of the Richards equation for variably saturated subsurface flow in the

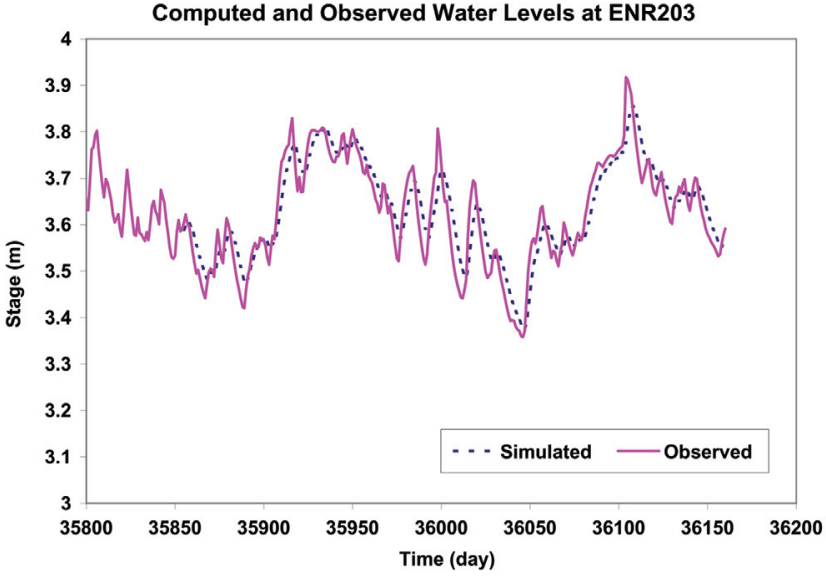

Fig. 6. Simulated and observed surface water levels at ENR301.

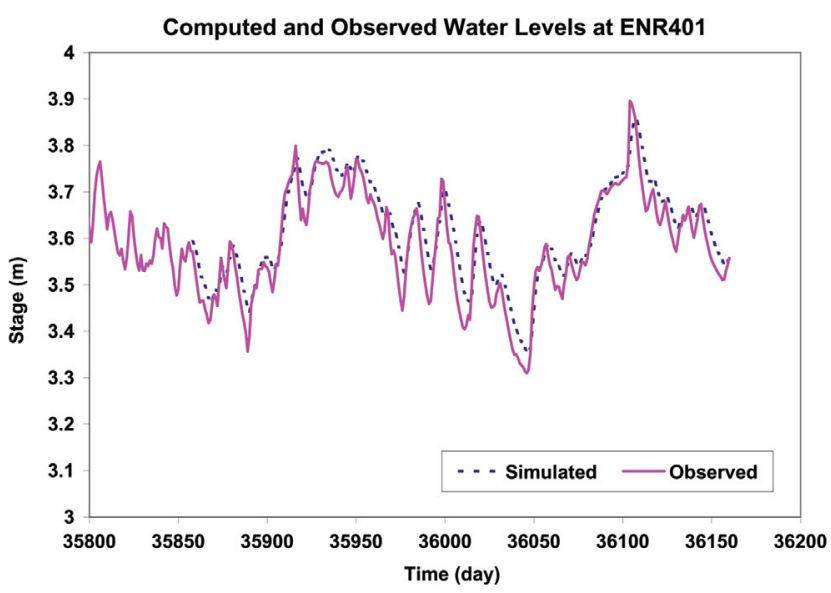

Fig. 8. Simulated and observed surface water levels at ENR401.

model is justified. As a matter of fact, previous SFWMD STA water budget studies (Huebner 2001) applied a regression equation to account for soil water storage during dry seasons.

The total head distribution on 2/4/1998 was plotted in Figs. 13 and 14. The simulated flow pattern of subsurface flow is consistent with field studies.

\subsection{Exchange Fluxes}

The vertical exchange fluxes between surface water and subsurface water flows were obtained as part of the model simulation (Fig. 15). The spatial distribution of the vertical fluxes was generally consistent with field observations of vertical hydraulic gradients distribution (Harvey et al. 2002). Groundwater discharge occurred only in the areas along the eastern boundary (L-7 canal) and groundwater recharge (infiltration of overland water) was significant along the seepage canal. Furthermore, the computed vertical flux values ranged from -0.75 to $2.0 \mathrm{~cm} \mathrm{day}^{-1}$. These values are 
within the range of seepage-meter measurements during 1997 - 1998 at the ENR site that is documented by Harvey et al. (2002).

\section{DISCUSSIONS ON MODEL SENSITIVITY AND UNCERTAINTY}

The model-independent parameter estimation and uncertainty analysis package PEST (Doherty and Johnston
2003) was applied in historical matching. This is performed by trying to minimize the absolute difference between observed and simulated surface and groundwater water levels.

The relative sensitivity of model parameters obtained with PEST (Fig. 16) shows that for a coupled system, the vertical hydraulic conductivity is the most sensitive parameter, the next is Manning's roughness coefficient (n values). The horizontal hydraulic conductivity values are the least sensitive.

Table 2. Summary of simulation errors in surface water levels.

\begin{tabular}{ccccc}
\hline Location & $\begin{array}{c}\text { Mean error } \\
(\mathbf{c m})\end{array}$ & $\begin{array}{c}\text { Mean absolute } \\
\text { error }(\mathbf{c m})\end{array}$ & $\begin{array}{c}\text { Root Mean Square } \\
\text { error }(\mathbf{c m})\end{array}$ & $\mathbf{R}^{\mathbf{2}}$ \\
\hline ENR101 & 5.62 & 5.88 & 0.21 & 0.91 \\
ENR203 & 0.58 & 3.62 & 0.10 & 0.85 \\
ENR301 & -4.51 & 4.51 & 0.13 & 0.95 \\
ENR401 & 2.85 & 1.73 & 0.10 & 0.91 \\
\hline
\end{tabular}

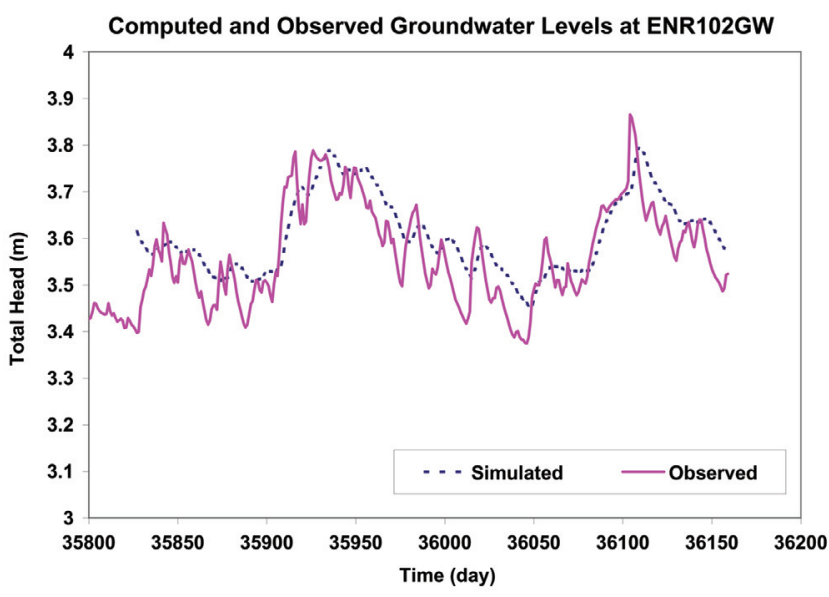

Fig. 9. Simulated and observed groundwater levels at ENR102GW.

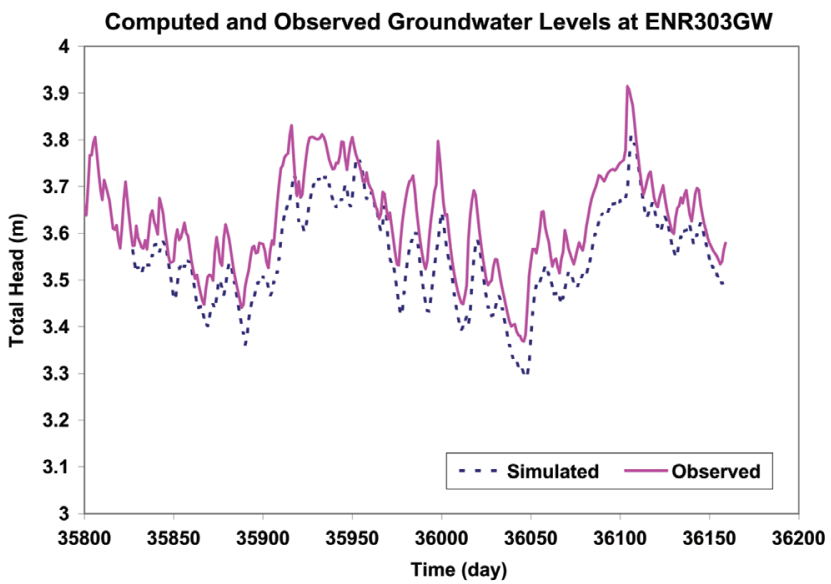

Fig. 11. Simulated and observed groundwater levels at ENR203GW.

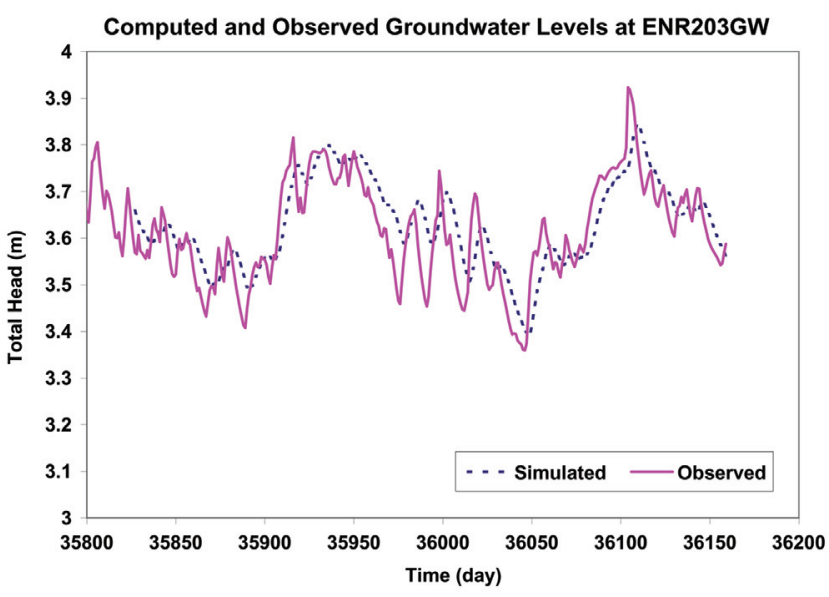

Fig. 10. Simulated and observed groundwater levels at ENR303GW.

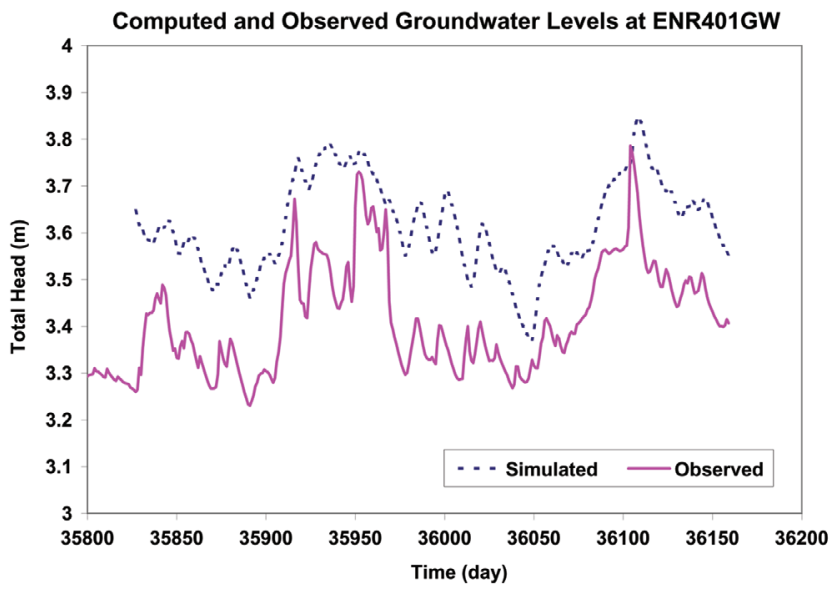

Fig. 12. Simulated and observed groundwater levels at ENR401GW. 
Table 3. Summary of simulation errors in groundwater levels.

\begin{tabular}{ccccc}
\hline Location & $\begin{array}{c}\text { Mean error } \\
(\mathbf{c m})\end{array}$ & $\begin{array}{c}\text { Mean absolute } \\
\text { error }(\mathbf{c m})\end{array}$ & $\begin{array}{c}\text { Root Mean Square } \\
\text { error }(\mathbf{c m})\end{array}$ & $\mathbf{R}^{2}$ \\
\hline ENR102GW & 3.30 & 5.62 & 0.22 & 0.68 \\
ENR203GW & 0.50 & 6.64 & 2.35 & 0.66 \\
ENR303GW & -8.59 & 8.62 & 2.48 & 0.84 \\
ENR401GW & 19.19 & 19.21 & 2.06 & 0.67 \\
\hline
\end{tabular}
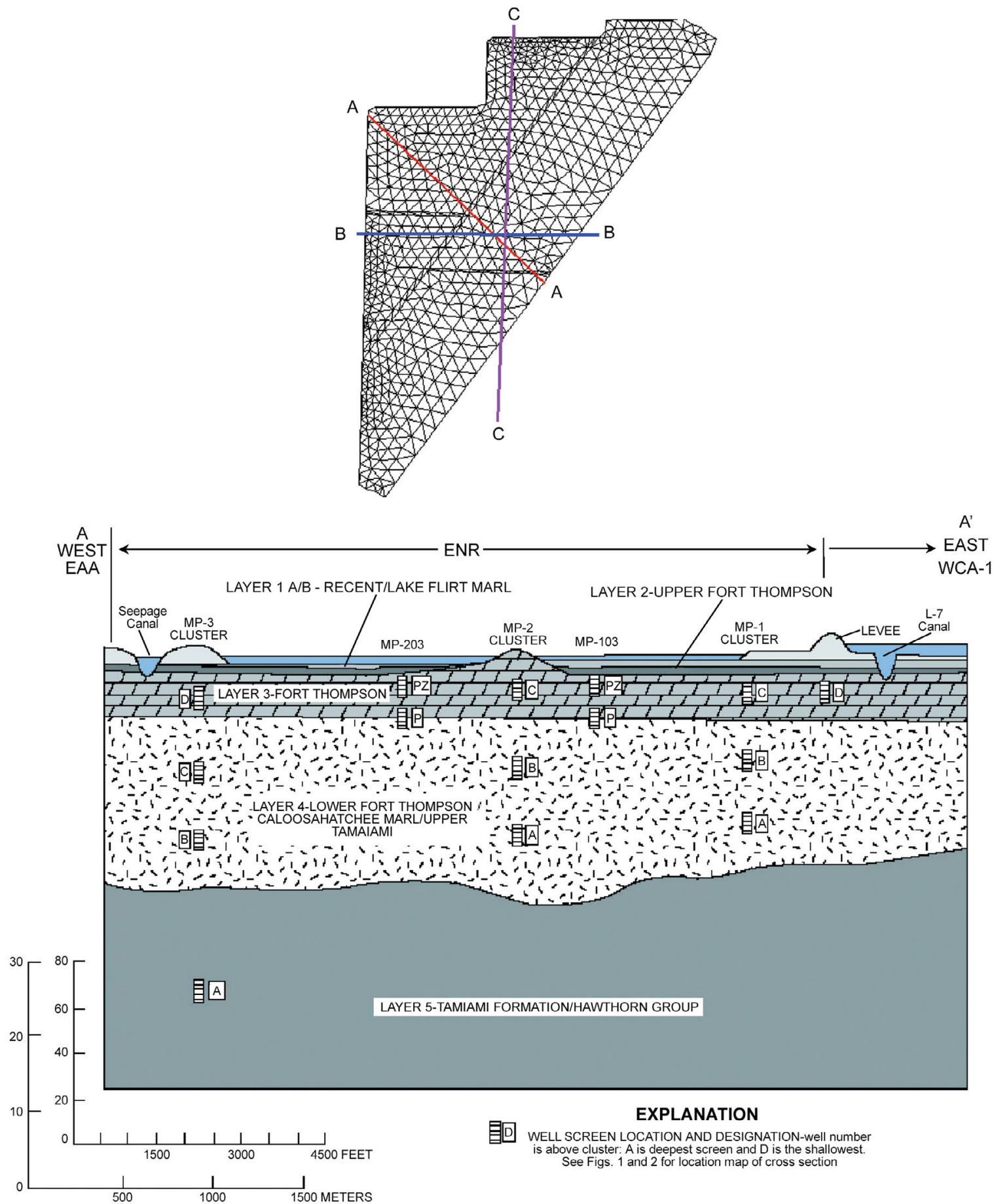

Fig. 13. Location of transects and lithology of ENR (after Harvey et al. 2002). 


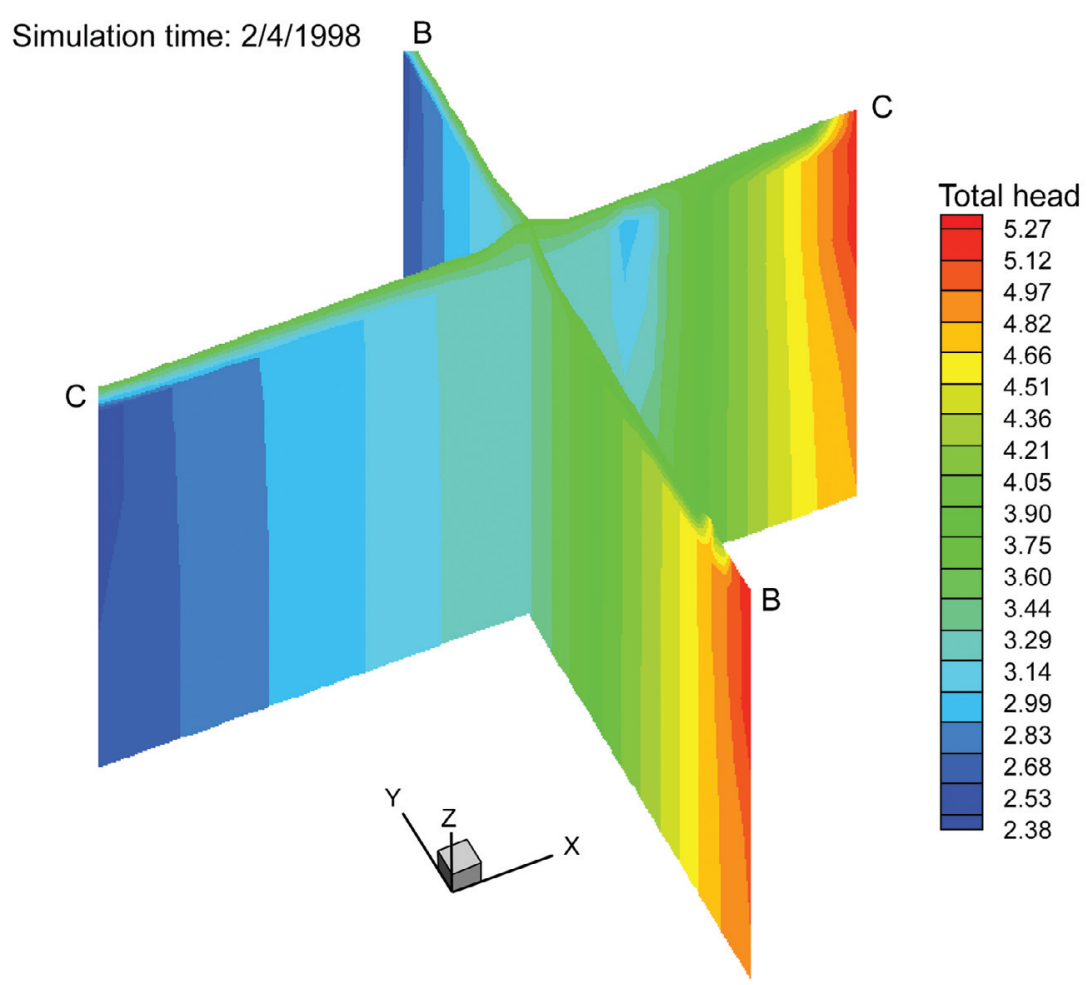

Fig. 14. Total head distribution (2/4/1998) for two transects of ENR (ft. NGVD).
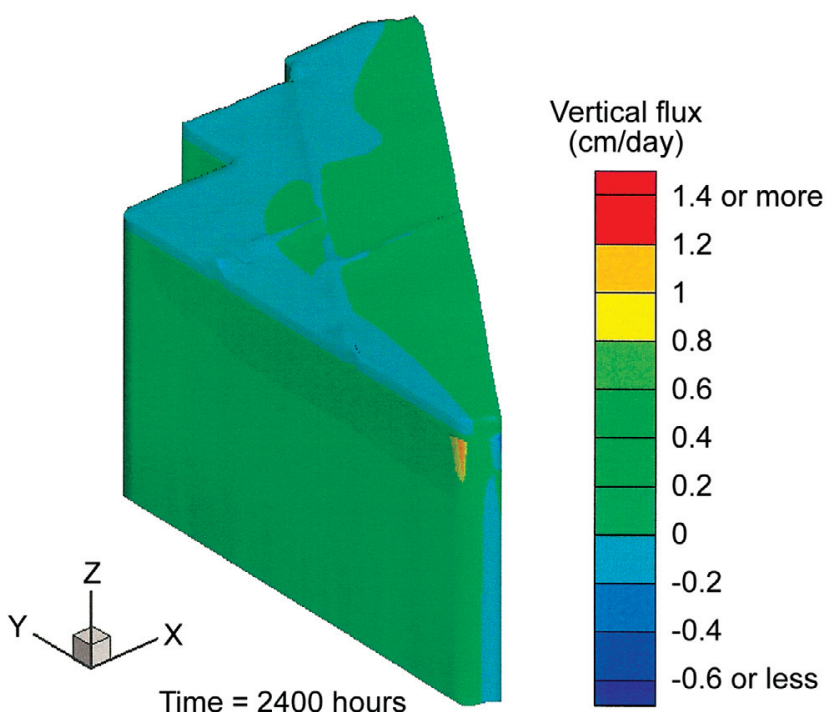

Fig. 15. Distribution of computed vertical flux $\left(\mathrm{cm} \mathrm{day}^{-1}\right)(4 / 11 / 1998)$.

Unlike some other similar integrated models, the coupling and exchange fluxes were not based on the assumption of interface discontinuity and leakage coefficient. Both continuity of pressure head and exchange flux were imposed; this avoided the historical matching of the empirical leakage coefficients for overland/subsurface and canal/subsurface interfaces necessary in other models (Huang and Yeh 2009).

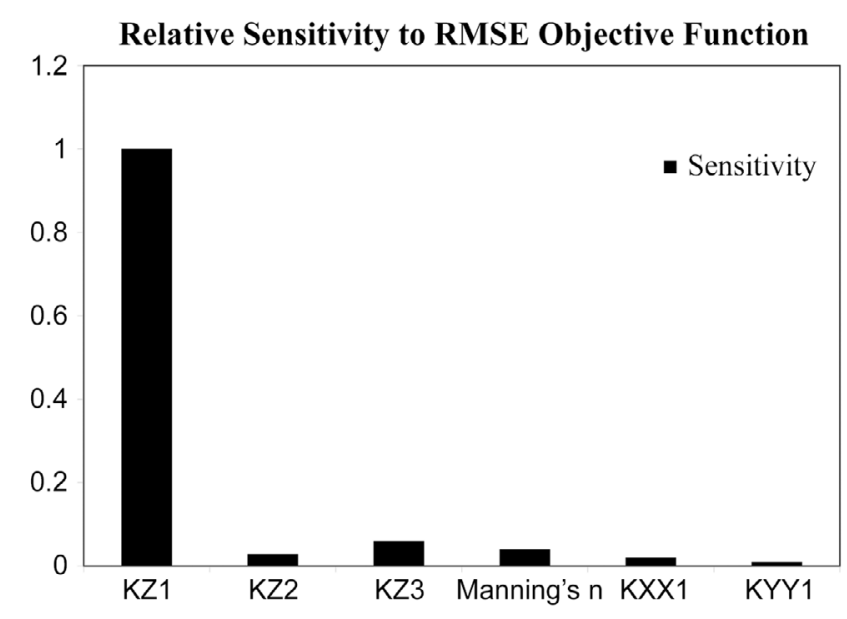

Fig. 16. Normalized relative sensitivity of model parameters.

The weak permeable peat that restricts vertical subsurface flow was part of the subsurface domain. The model simulation results in term of surface water levels, groundwater table, and exchange fluxes, among others demonstrate that this coupling approach is aligned to the physical processes of the ENR hydrology.

Details, in terms of variables such as vegetation type, 
local remnant ditches in the marsh, and culvert flow computation, among others could more accurately model twodimensional overland flow. A dynamic wave model of overland flow, to replace the diffusion wave approximation and the use of high-resolution time series data (e.g., 15 minutes observed data instead of daily average data used in current model simulations), may better simulate the high-frequency dynamic variation. Although the simulation results show that diffusion wave approximation is sufficient for overland flow.

\section{SUMMARY AND CONCLUSIONS}

A physics-based, integrated model was developed to simulate complex hydrologic processes in a constructed wetland. The surface water and groundwater interactions were simulated by coupled two-dimensional overland flow and three-dimensional subsurface flow. Minimum model historical matching, combined with model parameters estimated from field studies were able to reproduce major trends in historic surface and groundwater levels. And the model provides detailed spatial distribution of state variables and fluxes.

Acknowledgements The authors thank for the very valuable comments from two anonymous reviewers which greatly improved the quality of the paper.

\section{REFERENCES}

Abtew, W., 1996: Evapotranspiration measurements and modeling for three wetland systems in South Florida. $J$. Am. Water Resour. Assoc., 32, 465-473, doi: 10.1111/ j.1752-1688.1996.tb04044.x. [Link]

Abtew, W. and J. Obeysekera, 1995: Lysimeter study of evapotranspiration of cattails and comparison of three estimation methods. Trans. ASAE, 38, 121-129.

Doherty, J. and J. M. Johnston, 2003: Methodologies for calibration and predictive analysis of a watershed model. J. Am. Water Resour. Assoc., 39, 251-265, doi: 10. 1111/j.1752-1688.2003.tb04381.x. [Link]

Feng, K. and F. J. Molz, 1997: A 2-D, diffusion-based, wetland flow model. J. Hydrol., 196, 230-250, doi: 10.10 16/S0022-1694(96)03282-9. [Link]

Fish, J. E., 1988: Hydrogeology, aquifer characteristics, and ground-water flow of the Surficial Aquifer system, Broward County, Florida, US Geological Survey Water Resources Investigations Report 87-4034, p. 92.

Guardo, M., 1999: Hydrologic balance for a subtropical treatment wetland constructed for nutrient removal. Ecol.Eng., 12, 315-337, doi: 10.1016/S0925-8574(98) 00076-7. [Link]

Guardo, M. and R. S. Tomasello, 1995: Hydrodynamic simulations of a constructed wetland in south Florida. $J$.
Am. Water Resour. Assoc., 31, 687-701, doi: 10.1111/ j.1752-1688.1995.tb03394.x. [Link]

Harvey, J. W., S. L. Krupa, C. Gefvert, R. H. Mooney, J. Choi, S. A. King, and J. Giddings, 2002: Interactions between surface water and ground water and effects on mercury transport in the North-central Everglades. US Geological Survey Water Resources Investigations Report 02-4050, 91 pp.

Huang, G. and G. T. Yeh, 2009: Comparative study of coupling approaches for surface water and subsurface interactions. J. Hydrol. Eng., 14, 453-462, doi: 10.1061/ (ASCE)HE.1943-5584.0000017. [Link]

Huebner, S. R., 2001: Water budget analysis for Stormwater Treatment Area 6, Section 1. Technical Publication SFWMD-100, Water Quality Assessment Division, Environmental Resource Assessment Department, South Florida Water Management District, Florida, USA.

Langevin, C., E. Swain, and M. Wolfert, 2005: Simulation of integrated surface-water/ground-water flow and salinity for a coastal wetland and adjacent estuary. J. Hydrol., 314, 212-234, doi: 10.1016/j.jhydrol.2005.04. 015. [Link]

SFWMD (South Florida Water Management District), 2000: Stormwater Treatment Areas. 2000 everglades consolidated report, Chapter 6, Florida, USA.

SFWMD (South Florida Water Management District), 2005: DBHYDRO: available at: http://www.sfwmd.gov/dbhydroplsq1/show dbkey info.main menu.

Swain, E. D., M. A. Wolfert, J. D. Bales, and C. R. Goodwin, 2004: Two-dimensional hydrodynamic simulation of surface-water flow and transport to Florida Bay through the Southern Inland and Coastal Systems (SICS). US Geological Survey Water-Resources Investigations report 03-4287, available at: http://sofia. usgs.gov/publications/wri/03-4287/.

Thompson, J. R., H. Refstrup Sørenson, H. Gavin, and A. Refsgaard, 2004: Application of the coupled MIKE SHE/MIKE 11 modelling system to a lowland wet grassland in southeast England. J. Hydrol., 293, 151179, doi: 10.1016/j.jhydrol.2004.01.017. [Link]

Wu, F. C., H. W. Shen, and Y. J. Chou, 1999: Variation of roughness coefficients for unsubmerged and submerged vegetations. J. Hydraul. Eng., 125, 934-942, doi: 10.10 61/(ASCE)0733-9429(1999)125:9(934). [Link]

Yeh, G. T., G. Huang, H. P. Cheng, F. Zhang, H. C. Lin, E. Edris, and D. Richards. 2006: A first principle, physics-based watershed model: WASH123D. In: Singh, V. P. and D. K. Frevert (Eds.), Watershed Models, CRC Press, Boca Raton, Florida, USA.

Yen, B. C., 1992: Hydraulic resistance in open channels. In: Yen, B. C. (Ed.), Channel Flow Resistance: Centennial of Manning's formula, Water Resources Publications, Littleton, Colorado, USA. 